theme 5

society

author(s) strand 3

design ethics

\title{
The Role of The Designer in the New Social Symphony
}

The complexity of the brain's lateralization - when combined with the tendency to dichotomize and, thus, to create myths as part of the dissemination of scientific knowledge - determines the prudence with which neuroscientists approach this subject. Taking this fact into account, this work is based on the idea that design, as an agent of change, is only possible through a deeper development of the activities associated with the right hemisphere of the brain. Nowadays, these activities can be measured through functional magnetic resonances that simultaneously allow us to visualize the changes in the brain's functional cartography that are operated by neuroplasticity.

Knowledge based on logic and rational thought still plays an essential role in education, but the demand for aesthetic relevance (as defended by John Haskett) and ethic relevance (as defended by Francisco Varela) we are currently undergoing, encourages us to stimulate creativity (in the first case) - which is responsible for calculus, arts and design - as well as empathy and social responsibility (in the second case) - which guide our actions. In this sense, we should question the very foundations of education practices in general, and illustrate the need to promote the development of activities attributed to the right hemisphere of the brain by lateralists such as Daniel Pink, activities that have been systematically neglected so far.

Based on this assumption, this paper's perspective of design is mainly connected to the role it plays within cognitive development, fighting disease and social solidarity.

keywords empathy, right hemisphere, education, social design

\section{Introduction}

\section{Neuroplasticity and Brain Cartography}

Neuroplasticity can be understood as the brain's ability to reorganize itself when submitted to changes. This is a somewhat recent concept: not long ago, the immutable structure of the brain in its adult state was an accepted fact and it was believed that neurons died without others being born to replace them. Today it's a proven fact that neurogenesis exists, although neurons are born at a much slower rate than they die'. But brain plasticity is even more important if one considers the number and quality of synapses - the functional connections between neurons - that can multiply through the whole of our life. Experience leaves a footprint in memory, a "trace" (in psychoanalysis) that modulates 
behaviour, and the brain possesses fine mechanisms to store these pieces of information and to manage their recall whenever necessary. In cases of strong reinforcements of the trace, the modulation can be of such a degree that it can even alter a function of a component of the brain, like in the case of the chess champion, Susan Polgar². As a result of brain imaging tests, it was possible to better understand the process utilised in Polgar's 60 -second chess games. Functional magnetic resonance actually verified that Polgar used the fusiform gyrus - a component of the brain responsible for facial recognition - as a recognition device for chess configurations, allowing decisions to be taken as fast as our most intuitive responses, like recognizing a face or avoiding a collision trajectory.

Neuroplasticity can also be verified by the existence of savants, cases in which an injury (often innate, as in the case of prodigious savants) in the left hemisphere of the brain can be compensated by the liberation of some areas in the right hemisphere, thus unchaining a compulsive creativity in fields such as calculus or music.

We identify therefore the two aspects that interest us: the existence of the brain's lateralization, pointed out by the discovery (by Paul Broca, in 1861) of the area responsible for speech, located in the frontal lobe of the left hemisphere; and the fact that neuroplasticity may provide compensation to one of the hemispheres, in order to safeguard certain functions, in the case of dysfunction or injuries that disable specific areas of the other hemisphere.

This paper is based on the idea that design, as an agent of change, is only possible through a deeper development of the activities associated with the right hemisphere of the brain. Nowadays, these activities can be measured through functional magnetic resonances that simultaneously allow us to see the changes in the brain's functional cartography that are operated by neuroplasticity ${ }^{3}$

\section{Empathy and Design}

Although the activity of the right hemisphere is vital for creativity and artistic production, we also need - as seen in the case of the savants - the full operation of the left hemisphere. If the left hemisphere doesn't inhibit the right hemisphere's activity, there is an increase in creativity and effectiveness in the communication between both, since both hemispheres are connected by a thick tissue called "corpus callosum" that allows message sharing at an incredibly high speed between them. The speed and effectiveness concerning the transmission of synaptic messages by a cell's axons to another cell's dendrites is operated by the neurotransmitters 4 .

As an activity concerned with the creation of aesthetically relevant solutions ${ }^{5}$, design works simultaneously with detail - the kind of activity that is ruled by the left hemisphere - but also in a gestalt perspective - which is a responsibility of the right hemisphere. Not only is creativity based in the right hemisphere, but also the intuitive, empathic and social abilities. As Daniel Pink points out "empathy plays an essential part in design, since good designers have to get inside the minds of whomever is living the experience of the product or service they are projecting (...). Here, empathy is firstly a winning quality for design related to

${ }^{2}$ Polgar, S. (2007), Make me a Genius, viewed 20 October 2010. http://susanpolgar.blogspot.com/2007/o8/national-geographic-my-brilliant-brain.html ${ }^{3}$ Cf. Ansermet, F and Magistretti, P (2004). À chacun son cerveau, Paris, France : Ed. Odile Jacob, pp. 43-44. ${ }^{4}$ Frith, C. (2007). Comment le cerveau crée notre universo mental. Paris, France: Ed. Odile Jacob, pp. 129-132. 5 Heskett, J. (2002). Toothpicks and Logos: Design in Everyday Life, London, U.K.: Oxford University Press, p72. 
marketability, but we'll see it is also a fundamental part of a meaningful life."'

According to Francisco Varela's writings on Ethics, active ethics isn't the result of "any axiomatic ethics system or even pragmatic moral injunctions. Its higher purpose is to respond to the requirements of a specific situation"7. Instead of following rules, empathy rather follows a kind of non-egocentric spontaneity, thus representing a bridge to alterity. Nowadays, empathy is playing a central role in the treatment of patients: Jodi Halpern, a specialist in Bioethics, defends the substitution at hospitals of a detached professional interest by a more empathic approach.

\section{Practices of Change}

As seen, in such places as hospitals, the role of design can be that of creating simultaneously winning and empathic solutions. In a society vastly more open to the importance of design and where designers better understand the effects of colour in environments, as well as other elements of interior design which influence people's well being, there is a close relation between the improvement of hospital interiors - often more conducive to depression than cure - and patients' recovery.

Daniel Pink gives some examples of studies conducted in hospitals, where changes to design have been made, and the conclusions are similar. One of these studies was conducted in different wings of the Montefiore Hospital, in Pittsburgh, - the first was grey and shadowy, while the second was modern, pleasant and sunny $\neg$-and demonstrated that the patients staying in rooms with lots of sunlight needed less painkillers in postoperative phase and were discharged up to two days sooner. All these improvements conform with António Damásio's conclusions that "the neurobiology of emotions and senses teaches us that joy and its variations are preferable than sadness and its associated effects, and are favourable to health and the creative fullness of our being". 8

Edward T. Hall's studies about hospital waiting rooms demonstrated that these places discouraged communication and privacy, and were incapable of providing the minimum level of comfort 9 . The improvement of hospital interiors, where the designer plays a crucial role, are feasible because of empathy but also because of the financial advantages resulting from the faster recovery of patients in public hospitals.

These examples can also be extended to social housing projects, where aesthetic concerns, together with the provision of activities in public spaces, can significantly improve the social environment and reduce delinquency. Nevertheless, this pragmatic side doesn't invalidate the emotional aspect of sympathy for others. Both market and social gains can be achieved through an empathic approach, recognising the ability to put ourselves in the other person's position to the degree of intuiting what that person is feeling.

${ }^{6}$ Pink, D. (2009). A nova Inteligência. Lisboa, Portugal: Ed. Academia do Livro, pp.181-183.

7Varela, F. (2004) Quel savoir pour l'Éthique? Action, sagesse et cognition. Paris, France: Ed. La Découverte, pp.116-117.

${ }^{8}$ Damásio, A. (2003). Spinoza Avait Raison. Paris, France: Ed. Odile Jacob, p.267.

${ }^{9}$ Cf. Hall, E. (1972) A Dimensão Oculta. Lisboa, Portugal: Ed. Relógio d'Água, pp.127-130. 


\section{An Education Based on Design}

According to Donald Norman, "Design is an exciting powerful field, filled with promise. To meet the challenges of the 21st century, design and design education must change". ${ }^{0}$ In fact, our educational culture is normally based on the logical, sequential and analytic. As a result of this radical dominance, students enter universities with an evident inaptitude for thinking intuitively and for working within the convergence of several disciplines, since they aren't sensitive to the general context, nor can they embrace gestalt perspectives.

This exacerbation is actually responsible for the nonexistence of intuition-based decisions coming from the pre-fontal areas of the brain. However, these usually correspond to intuitions that come prior to reason and that work as smart and sensible guesses, which make our task solving processes faster and more effective. These kinds of decisions also have a more empathic character, since we're talking about the area of the brain responsible for emotions, as Hanna and António Damásio's works have shown us. ${ }^{11}$ When this kind of decision takes place, the prefrontal areas are very active and creativity operates with less inhibitions. The more we engage in the creative flux (as defended by Csikszentmihaily ${ }^{12}$ ), the more we escape the tyranny of the conceptual order, unattached to a sensorial origin. Nevertheless, the judgemental work that comes after the creative process calls for the application of conscious reason, so that the spontaneous creativity can be fine-tuned and given credibility.

When criticising education it is essential to consider a certain number of high schools in some countries where the curriculum is design focused. Daniel Pink gives several examples of these kinds of schools, such as CHAD (Charter High School for Architecture and Design), in Philadelphia. The taught disciplines are Industrial Design, Architecture, Colour Theory and painting, and the basic disciplines, such as Maths, Science, English and Social Studies are taught in connection to Design. As an example, Pink uses the Roman Empire, where students didn't only study how the water was transported, but also how to build an aqueduct. Students should learn how to search for all the information and materials required for the given tasks, and how to use a variety of different disciplines in order to find solutions. Furthermore, these solutions should be sustainable, taking into account a deep respect for the environment.

According to CHAD's board, these practices are intrinsic to what a designer is or should be: a detective looking for aesthetic and optimized solutions, which he previously interiorized in his neuronal circuits through an interdisciplinary strategy: the transversal education of students must provide them with a gestalt and contextualized though ${ }^{13}$. For the reasons stated above, Barbara Chandler Allen from CHAD considers that if design introduces an aesthetic dimension, as well as pleasure and meaning to our lives, then to be a designer is to be an agent of change ${ }^{14}$.

\footnotetext{
${ }^{10}$ Norman, D. and Klemmer, S. (2014). "State of Design: How Design Education Must Change". http://www.linkedin.com/today/post/article/20140325102438-12181762-state-of-design-how-designeducation-must-change?trk=eml-ced-b-art-M-o\&midToken=AQH4OcvpZt7xdQ\&ut=1duQqHyDRG_681 "Cf. Damásio, A. (1997). O Erro de Descartes: Emoção, Razão e Cérebro Humano. Lisboa, Portugal: Ed. Europa-América, p.64. ${ }^{12}$ Cf. Csikszentmihaily, M. (2002). Fluir. Lisboa. Portugal: Ed. Relógio d’Água, pp. 107-115. ${ }^{13}$ Cf. Pink, D. (2009). A Nova Inteligência. Lisboa, Portugal: Ed. Academia do Livro, pp. 90-91. ${ }^{14} \mathrm{Cf}$. Ibid, p. 106.
} 


\section{Aesthetic Relevance}

If technical quality may be similar across many brands, design can really make a difference. This was always Sony's philosophy, for example. By acting in accordance with that philosophy, companies are attending to the requirements of aesthetic relevance. Pink makes a very lucid remark that demonstrates the legitimacy of this requirement, by pointing out that most toasters are used a maximum of 15 minutes a day ${ }^{15}$. In fact, the rest of the time it's just lying there, exhibiting its shape in silence. If, as well as toasting bread correctly, the toaster is pleasant to look at, it will be performing perfectly.

Nowadays, it's actually difficult to find a toaster that isn't anything else besides itself, since it is usually at least a reprise of another toaster immortalized by design. We have come to the point where we are eating toast with images of our favourite heroes. It's natural that we feel happier if shapes are welcoming and ludic, whilst simultaneously providing quality of life and sustainability.

In 1995 Sergio Asti brought back to life the autoseltz, an object that makes us travel back in time to meet Apollinaire, as he describes the Paris of bars and the effervescent futurism of the autoselz. In a text of Vitor Margolin yet to be published, the author gives an account of the traditional use of the autoselz, and points out how it's reinterpretation by contemporaneity added value to people's everyday life.

\section{Ethics and Design}

In this time of abundance for some, contrasting with total scarcity for others, Robert William Fogel (Nobel Prize of Economy) writes that "a great problem of our times is iniquity, but immaterial inequity is probably even greater then material inequity". ${ }^{16}$

Considering that education should guide intuition through a deeper development of the right hemisphere of the brain, so that intuition can be the key for decision criteria concerning ethics, we again quote Francisco Varela, when he states that Ethics is based on the sensitiveness to the specificity and immediatism of lived experiences "rather than on the pure and simple appliance of usual rules" 17. The spontaneity that arises from these experiences results in openness to alterity.

Taking into account the progressive receptiveness to the influence of design in many fields, the designer - as someone who should and is being taught how to give better use to empathy and intuition, powered by a greater development of the right hemisphere of the brain - will be in a privileged situation to make fundamental changes in the quality of people's lives and towards a planetary sustainability. 


\section{References}

Ansermet, F. \& P. Magistretti. (2004). À chacun son cerveau. Paris: Odile Jacob.

Berthoz, A. (2013). La vicariance: le cerveau créateur de mondes. Paris: Odile Jacob. Berthoz A. \& G. Jorland (2004). L'Empathie. Paris: Odile Jacob.

Csikszentmihaily, M. (2002). Fluir. Lisboa: Ed. Relógio d’Água.

Cymes, M. (2008). Préface: Doidge, N. Les étonnants pouvoirs de transformation du cerveau. Paris: Belfond.

Damásio, A. (2010). O livro da consciência: a construção do cérebro consciente. Lisboa: Temas e Debates.

Damásio, A. (2003). Spinoza avait raszon. Paris: Ed. Odile Jacob.

Damásio, A. (1995). O erro de Descartes: emoção, razão e cérebro humano. Lisboa:

Publicações Europa - América.

Dehaene,S \& C. Petit (2009). Parole et musique. Paris: Odile Jacob.

Doidge, N. (2008). Les étonnants pouvoirs de transformation du cerveau. Paris: Belfond. Eersel, van P. (Ed) (2012). Interview with André, C. Les émotions se trouvent au coeur de la plasticité cerebral. Votre cerveau n’a pas fini de vous étonner. Paris: Albin Michel. Eric, C. \& G. Schalk \& J. Roland \& A. Rouse \& D. Moran. (2009). Evolution of braincomputer interfaces: going beyond classic motor physiology. Retrieved from http://thejns. org/doi/full/10.3171/2009.4.FOCUSO979

Forbes, C. (1992). The Polgar Sisters: Training or genius? New York: Henry Holt \& Company.

Hall, E. (1972). A dimensão oculta. Lisboa: Ed. Relógio d’Água.

Kowalski, C. (2008). OCZ's Neural Impulse Actuator - The flying car of control schemes. Retrieved from http://techreport.com/articles.x/14957

Marendaz, C. (2009). Du regard à l'émotion : la vision, le cerveau, l'affectif. Paris: Le Pommier.

Merzenich, M. (2013). Soft-Wired: How the New Science of Brain Plasticity Can Change your Life. San Francisco: Parnassus Publishing LLC.

Norman, D. and Klemmer, S. (2014). "State of Design: How Design Education Must Change". Retrieved from http://www.linkedin.com/today/post/article/2014032510243812181762-state-of-design-how-design-education-must-change?trk=eml-ced-b-art-Mo\&midToken=AQH4ocvpZt7xdQ\&ut=1duQqHyDRG_681

Pink, D. (2009). A nova Inteligência. Lisboa: Ed. Academia do Livro.

Polgar, S. \& P. Truong. (2005). Breaking Through: How the Polgar Sisters Changed the Game of Chess. London: Everyman Chess.

Polgar, S. (2007). Make me a genius. Retrieved from http://susanpolgar.blogspot. com/2007/o8/national-geographic-my-brilliant-brain.html

Varela, F. (2004). Quel savoir pour l'Éthique? Action, sagesse et cognition. Paris, France: Ed. La Découverte.

\section{Acknowledgements}

This work is funded by national funds through the Foundation for Science and Technology - FCT - in the scope of project PEst-OE/EAT/UI4057/2014.

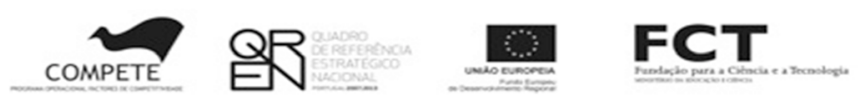


